\title{
When do service suppliers leave their platform?-The role of friendships
}

\section{Oliver Rossmannek ${ }^{1}$}

Received: 8 February 2021 / Accepted: 22 June 2021 / Published online: 2 July 2021

(c) The Author(s) 2021

\begin{abstract}
Platform organizations connect suppliers with customers. A key success factor for these organizations is the maintenance of a stable base of loyal suppliers. Interpersonal relationships (i.e., friendships) seem to be an ideal measure of suppliers' loyalty, as the literature generally indicates that friendships within organizations decrease turnover intention. However, platforms are not fully comparable to traditional organizations, and the correlation between friendships and suppliers' turnover intention is more complicated for platforms. To demonstrate that, this study analyzed a unique dataset from the music industry. The sample included 101 techno DJs (i.e., service suppliers) from 61 booking agencies (i.e., service platforms). The findings show that service suppliers' turnover intention is considerably lower when they maintain friendships with the platform's employees. However, friendships with other suppliers who use the same platform do not affect turnover intention. Managers of service platforms could use the results and suggestions of this paper to adapt their management practices to better suit their service suppliers.
\end{abstract}

Keywords Platforms · Service suppliers $\cdot$ Turnover $\cdot$ Friendships $\cdot$ DJs $\cdot$ Booking agencies

\section{JEL Classification M54}

\section{Introduction}

In recent years, online service platforms (e.g., Airbnb, Uber, TaskRabbit) have received much attention both inside and outside of academia (Wirtz et al. 2019). However, service platforms are not a new phenomenon (Edelman 2014), and there are many examples of offline service platforms, such as staffing agencies and

Oliver Rossmannek

oliver.rossmannek@vwl.uni-freiburg.de

1 Institute of Economics and Business Administration Rempartstraße 16, Albert-Ludwigs-

University of Freiburg, 79098 Freiburg, Germany 
temporary work agencies (Chen et al. 2017; Ruiner et al. 2019). In general, service platforms are two- or multi-sided markets that connect service suppliers with potential customers (Eisenmann et al. 2006). By creating this connection, the platforms provide rules and infrastructure for all sides of the market (Fu et al. 2017; Parker and van Alstyne 2014; Song et al. 2021). More precisely, service platforms often support service suppliers by performing tasks such as payment processing, performing authentication checks, and maintaining communication channels with customers (Meijerink and Keegan 2019).

A key success factor for both offline and online platforms is the maintenance of a loyal base of service suppliers (Andreassen et al. 2018; Hazée et al. 2020). However, previous research into service platforms and turnover intention (i.e., the willingness to leave the platform) has generally concentrated on the customer side of the equation (Akhmedova et al. 2020; Clauss et al. 2019; Huarng and Yu 2019). Empirical studies analyzing antecedents of service suppliers' turnover intention are scarce. The existing research on the supplier side shows that the suppliers' participation in the platform's activities (Ma et al. 2018), their trust in the platform (Chen et al. 2009), and their perceptions of the platform's quality (Wang et al. 2020) all affect turnover intention. However, researchers have neglected the role of interpersonal relationships in suppliers' turnover intention. This is important, as interpersonal relationships can be a differentiating factor between platforms (Huang et al. 2017). For example, large online platforms such as Airbnb often place relatively little value on their interpersonal relationships with service suppliers, while smaller and more focused platforms can use interpersonal relationships to maintain a loyal base of suppliers and thus obtain a competitive advantage.

The view that interpersonal relationships affect service suppliers' turnover intention is strongly supported by research conducted within traditional organizations such as firms, the military, and sports teams (Holtom et al. 2008). Interpersonal relationships usually generate embeddedness in the focal organization, increasing the motivation to stay (Mitchell et al. 2001). Research has shown that interpersonal relationships inside and outside of an organization can affect turnover. Inside the organization, turnover is dependent on interpersonal relationships with coworkers and supervisors (Zhang et al. 2019). Outside the organization, turnover is affected by interpersonal relationships within the local community (Lee et al. 2004) and within the occupational network (Feldman and $\mathrm{Ng}$ 2007). Consequently, it is reasonable to assume that, in the context of a platform, interpersonal relationships will also affect suppliers' turnover intention, regardless of where they occur. In the following section, I will outline two hypotheses that follow this premise. However, in a platform context, the level at which the interpersonal relationships occur seems to be important.

To demonstrate this, I chose an empirical setting in which platform suppliers have intense and long-term personal contact with the platform's members: namely, performing artists and their booking agencies. This allowed me to conduct a detailed analysis of the influence of interpersonal relationships on turnover intention. Booking agencies fit within the definition of service platforms, as they work as two-sided markets and intermediates between service suppliers (i.e., artists) and customers (i.e., clubs and festivals; Eisenmann et al. 2006). Artists use their booking agencies 
as platforms on which to interact with a constantly changing customer base. Artists do not generally maintain long-lasting relationships with their customers (otherwise there would be little need for the platforms). However, the booking agents and other artists at the agency typically comprise a relatively stable set of interpersonal contacts. As a consequence, interpersonal relationships can occur on (1) the platform level (i.e., booking agents that are employees of the agency) and (2) the supplier level (i.e., other artists affiliated with the agency).

For my analysis, I identified 1,502 professional techno DJs who regularly perform in Germany. I contacted all the artists and was able to collect a sample of 101 DJs from 61 booking agencies. I employed friendships as the operationalization of interpersonal relationships. This study contributes to the field of managing service platforms by revealing what is (and is not) an important driver of suppliers' turnover intention. In short, friendships on the platform level are essential, while friendships on the supplier level appear to be irrelevant. Consequently, platform managers faced with high turnover rates should focus on building friendships between platform employees and service suppliers. A befriended community of service suppliers seems to have little impact on a platform's turnover rate.

\section{Hypothesis}

Scholars have long argued that interpersonal relationships affect turnover intention (Mitchell et al. 2001). However, previous research on this topic has been too narrow, often operationalizing relationships by solely the number of relationships (Lee et al. 2017). This method has two problems. First, the number of relationships alone has little predictive value, as there may be large differences between relationships in terms of their intensity (Lee et al. 2014). Second, the character of a relationship is important for understanding the effects of the relationship (Cropanzano et al. 2017). Regarding turnover, friendship appears to be a particularly important type of relationship. In contrast to formal business relationships, friendships are primarily focused on the private context (Mao 2006). Broadly defined, a friendship constitutes a strong and affective interpersonal relationship (Ingram and Zou 2008). Vardaman et al. (2015) showed that friendships among employees can significantly reduce employee-turnover intention. However, the authors found no significant effect of any other type of relationship (e.g., advice relationships) for turnover intention. Several other studies have also found that workplace friendships reduce turnover intention (Feeley et al. 2008; Riordan and Griffeth 1995). Consequently, this study focused on how friendships affect the turnover intention of platform suppliers.

Friendships represent a type of embeddedness in a platform (Lee et al. 2014; Mitchell et al. 2001). When service suppliers maintain friendships with a platform's employees or other suppliers, leaving one platform and joining another can have two severe consequences. First, the supplier is not initially as embedded in the new platform as they were in the old platform, as friendships are complex interpersonal relationships that take time to develop (Pillemer and Rothbard 2018). Being embedded in a friendship network has several valuable advantages for service suppliers. For example, friendships improve the performance of work relationships (Grayson 
2007), foster informal information channels (Boyd and Taylor 1998), and increase interpersonal trust (Lin and Hsieh 2011; Price and Arnould 1999). Moreover, friends provide social support that decreases the risk of burnout and increases job satisfaction (Baruch-Feldman et al. 2002). In addition, friendships often create a more harmonious work environment (Maertz et al. 2003), foster solidarity among colleagues (Koster et al. 2007), and improve work engagement (Jonas et al. 2018).

Second, maintaining friendships at the previous platform while working with a new one can be difficult for service suppliers. Before changing platform, the service supplier could use platform-related business interactions for friendly engagement (Grayson 2007). Without these platform-related interactions, a supplier must invest much more effort into maintaining the same friendships. Moreover, the employees and other service suppliers at the old platform might perceive the service supplier's turnover as a disloyal act. Hence, service suppliers who change platforms may fear that they will lose their friendships as a result. The potential loss of friends and the resources associated with old friendships (e.g., informal information) often burden suppliers with negative emotions that outweigh the positive emotions associated with forming new friendships at the new platform (Hobfoll 1989; Kiazad et al. 2015). More precisely, employees report feelings of isolation, frustration, and unhappiness when losing workplace friendships (Sias et al. 2004). The literature on workplace friendships suggests that they generally reduce turnover intention, regardless of the level at which they occur. Above, I outlined two levels of friendships relevant to service suppliers: namely, the platform level, where service suppliers form friendships with the platform employees; and the supplier level, where service suppliers form friendships with other suppliers affiliated with the same platform. Hence, my hypotheses are as follows:

H1a: Friendships with the staff of a platform decreases the suppliers' turnover intention.

H1b: Friendships with other platform suppliers decreases the suppliers' turnover intention.

\section{Method}

\subsection{Research context and sample}

To test the hypotheses, I conducted a survey-based study for service-platform suppliers. I focused on techno DJs ${ }^{1}$ (i.e., electronic music artists) and their booking agencies. The techno-music industry has seen rapid development in recent decades, resulting in a relatively high degree of professionalism among many entities in the industry, including clubs, festivals, booking agencies, and, of course, DJs. Although many DJs produce and sell their own music, music sales account only for a minor share of most DJs' total income (an average of 5.6\% in my sample). Performances

\footnotetext{
${ }^{1}$ In order to get an impression of leading global techno DJs, you can visit for example: https://www. techno-livesets.com/dj-list/.
} 
at clubs and festivals are the primary source of income for most DJs (an average of $63.2 \%$ in my sample). For example, Berlin's techno clubs alone accounted for approximately 70,000 DJ performances in 2018 (Damm and Drevenstedt 2019). In this industry, booking agencies are service platforms. They function as two-sided markets and intermediates between suppliers (i.e., DJs) and customers (i.e., clubs and festivals; Eisenmann et al. 2006). In my sample, the booking agencies maintain a database of several DJs (2-51 DJs per agency) and sell their performances to clubs and festivals around the world. Moreover, booking agencies often perform a number of support services for DJs, including negotiating prices, issuing contracts, and arranging travel (Cole 2013).

Before designing the study, I conducted several preliminary interviews with DJs, booking agents, and customers. Nearly all the interviewees stated that DJs frequently maintain friendships with the other DJs at their agencies, their booking agents, or both. In the rare cases where DJs maintain friendships with festival officials and club owners, they often circumvent their booking agencies and interact directly to organize performances with them (usually resulting in cost savings for their friends).

To assemble a study population, I identified professional DJs who had performed in Germany during 2017. I used Resident Advisor (a social networking website that focuses on electronic music) to identify the 20 most popular electronic music clubs. I also used festivalticker.de (a search engine for festivals) to identify the 20 most popular electronic music festivals (see Appendix A1). I collected data on every DJ performance in 2017 and identified the booking agencies of those DJs. For this purpose, I defined the DJ as a professional if he or she had performed in at least three different locations. If multiple DJs with a single booking agency met this condition, I categorized the entire booking agency as a professional entity and added all associated DJs to the study population. This resulted in a study population of 1,502 DJs and 113 booking agencies.

For the survey, I wrote to all booking agencies with a request to forward the personalized study invitation to their DJs. If I did not receive an answer from a particular DJ, I contacted that DJ directly (by email or Facebook). The study was conducted between June 2018 and January 2019. Ultimately, 115 DJs completed the survey. Due to incomplete responses, 14 DJs were removed from the sample, leaving a total of 101 DJs from 61 booking agencies (a response rate of $6.7 \%$ ). There was no indication that sample bias could influence my results because I had obtained responses from DJs associated with many of the original 113 booking agencies. Moreover, the gender ratios in the sample and the population are relatively equal (population: $9.9 \%$ female; sample: $8.9 \%$ female).

\subsection{Measures}

My model and all control variables are summarized in Fig. 1. All questions were asked in both German and English. For all latent variables, I applied established measurement scales (see Table 1) and used seven-point Likert scales ( $1=$ strongly disagree, $7=$ strongly agree). 


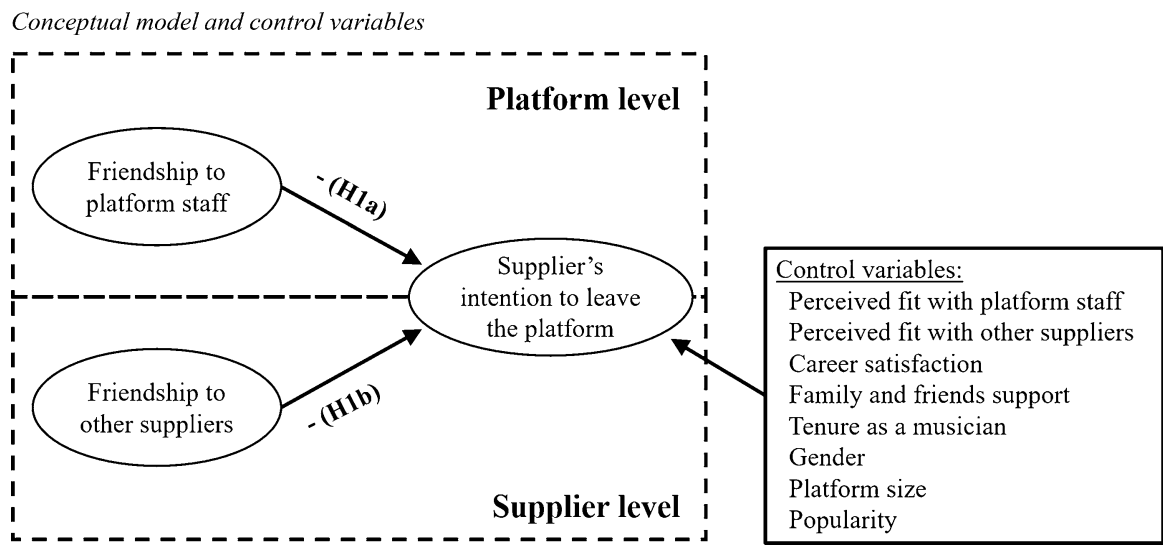

Fig. 1 Conceptual model and control variables

In addition to the hypothesized relationships, I used several latent and non-latent control variables. I included the perceived fit with the platform staff and with the other suppliers. Fit has been shown to affect turnover intention (Verquer et al. 2003). Moreover, fit in a business environment often correlates with workplace friendships (Gao et al. 2016; Sias and Cahill 1998). Hence, fit is an essential control variable.

Career satisfaction was also a latent control variable that measured the DJs' satisfaction with the progress of their careers, which is, to some extent, the result of the work of their booking agencies. Hence, this variable relates to job satisfaction in intra-organizational studies, which is a key control variable for studies on turnover intention (Lee et al. 2014). Moreover, career progress is a type of job performance that affects a person's turnover behavior (Bycio et al. 1990). Family and friends support served as a latent marker variable, which I used to detect common method biases (CMBs). This refers to the extent to which DJs feel that their loved ones support them in their profession.

Additionally, I used several non-latent control variables. First, I included a DJ's tenure as a musician (measured in years), as tenure can substantively affect turnover rates (Mitchel 1981). Second, I used gender (dummy variable: $1=$ female) as a control variable, as turnover behavior was shown to vary between genders (Blomme et al. 2010). Third, I obtained data on platform size (measured as the number of DJs per booking agency) via an online search. I included this variable because a platform's number of suppliers can affect the platform's attractiveness (Sun and Tse 2009). Fourth, a DJ's popularity is an indicator of his or her success, and this can affect a supplier's intention to use a particular platform (Kathuria et al. 2020). Therefore, I examined the number of followers the DJs had on Soundcloud (obtained by searching the website), as Soundcloud is arguably the most important online distribution channel for electronic music. Additionally, I collected data from two other social media websites regarding DJ popularity. Correlation coefficients indicated a relatively close fit with Soundcloud, but not all DJs maintained an account there (Facebook; $r=0.62$ [ $n=99]$, Resident Advisor: $r=0.55[n=98]$ ). 


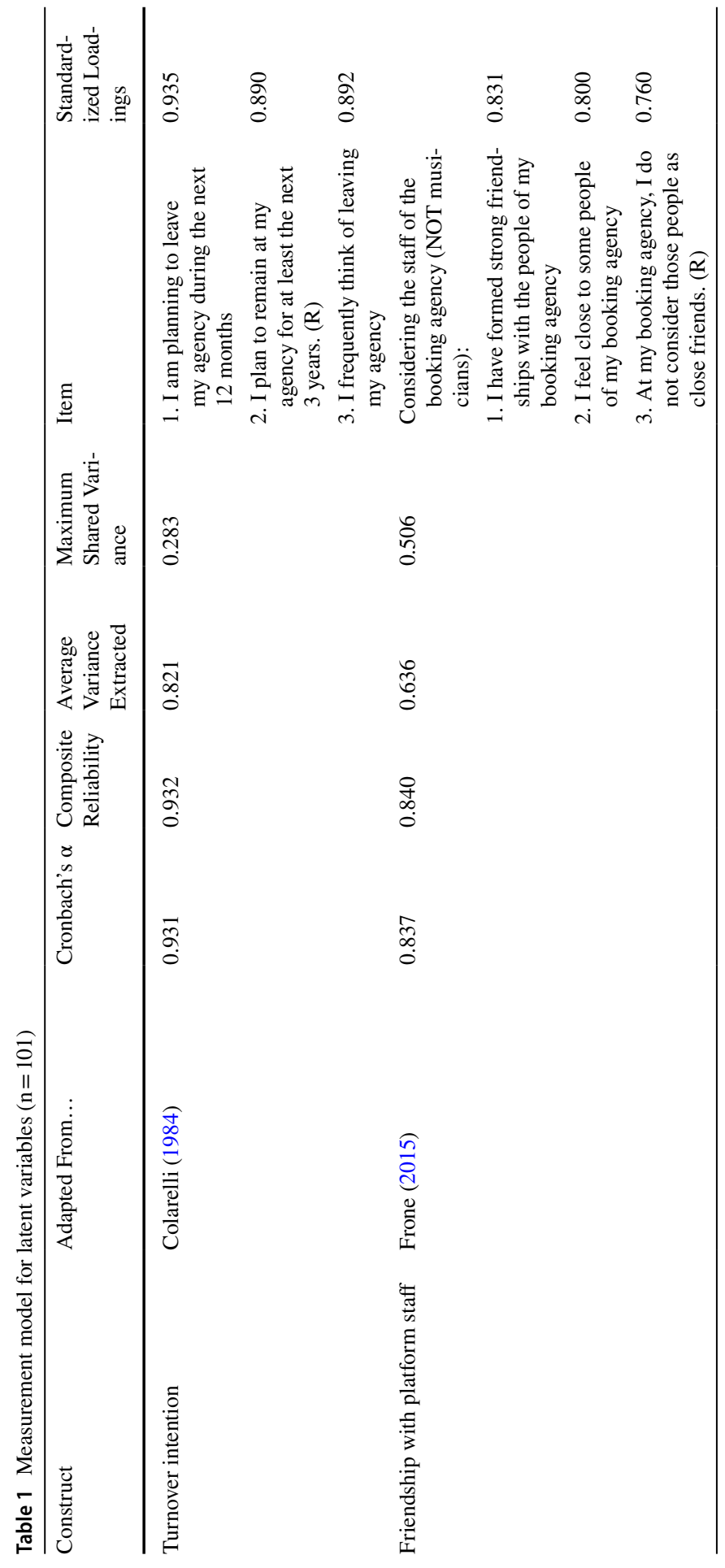




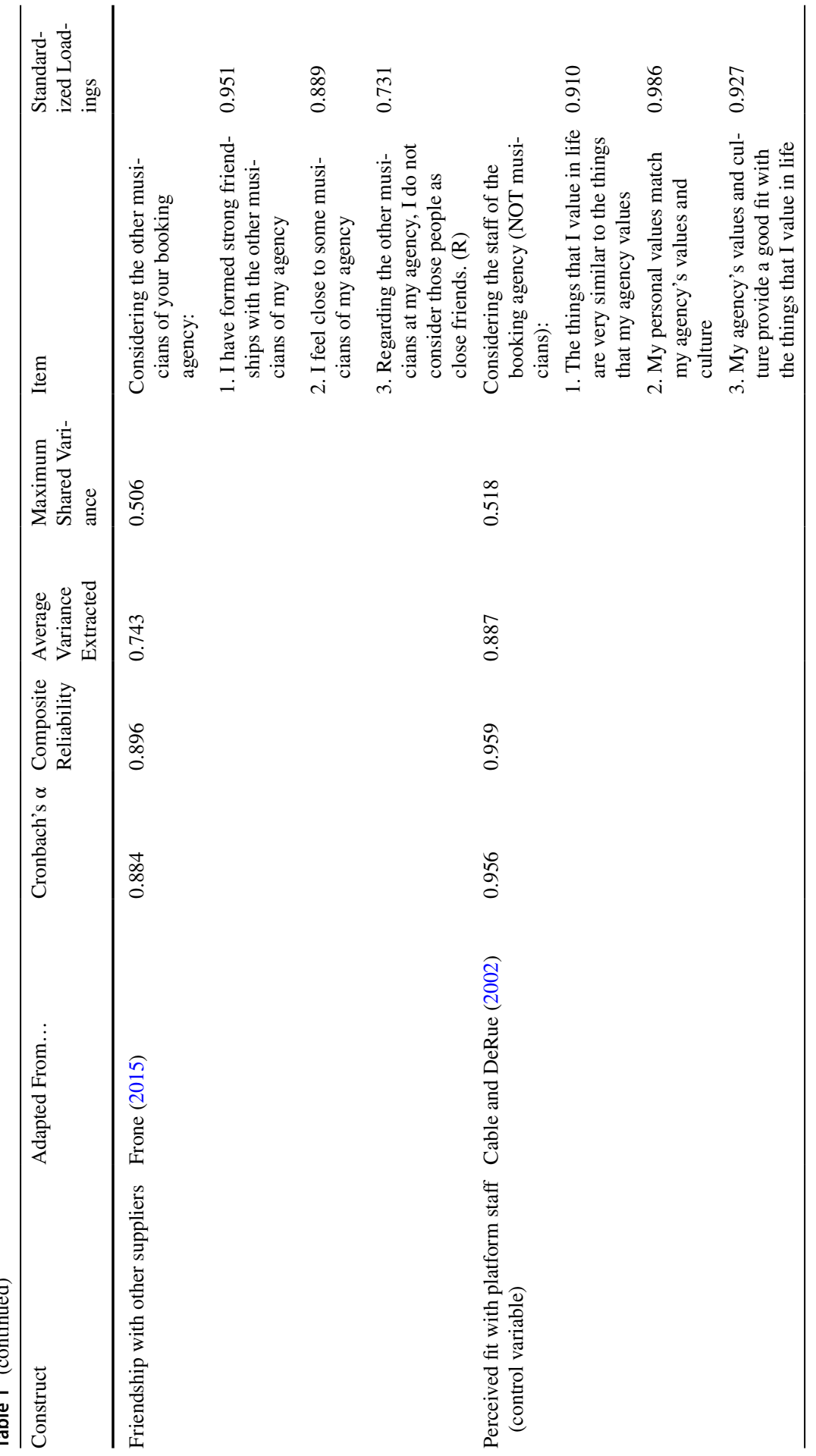




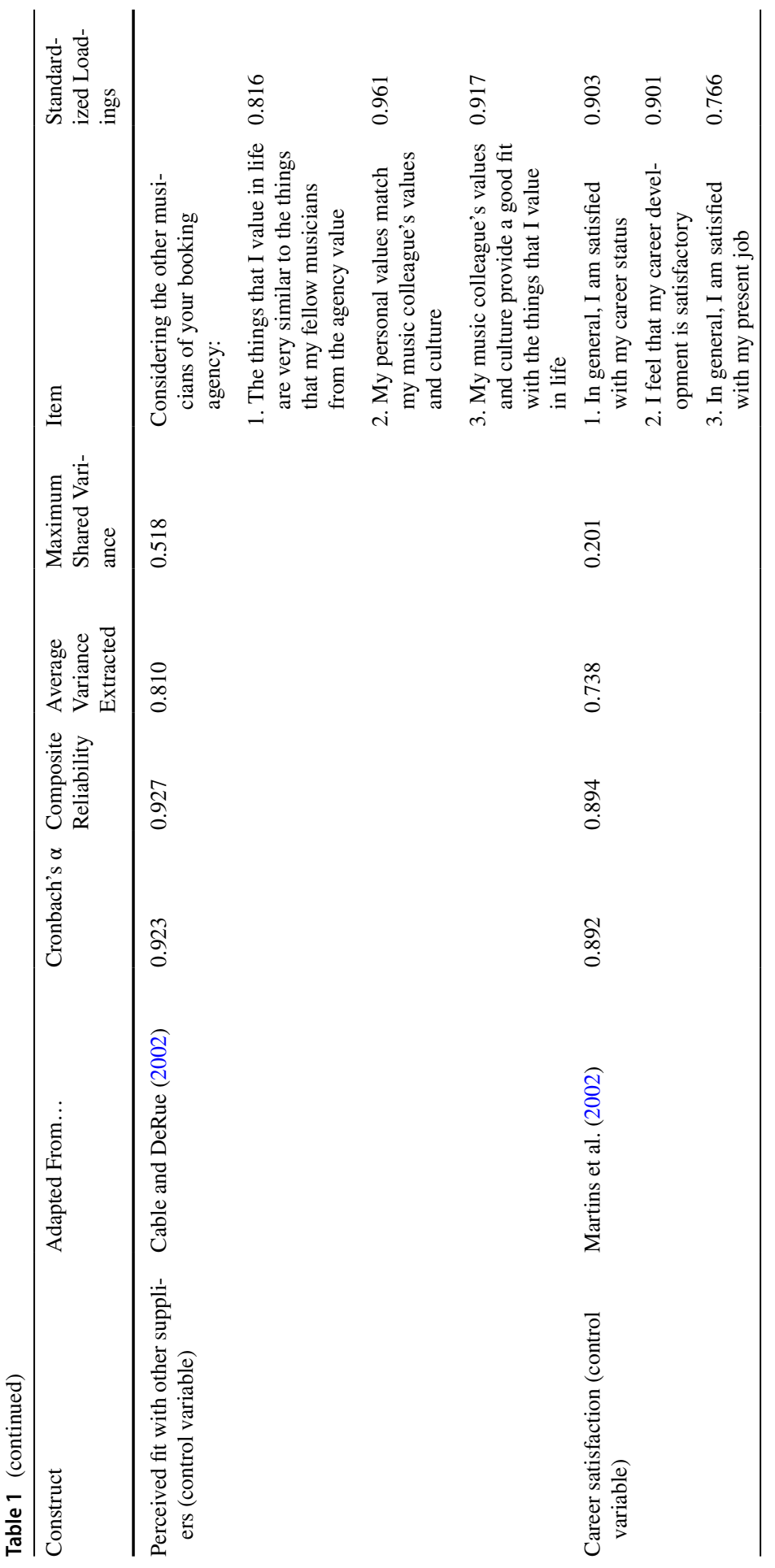




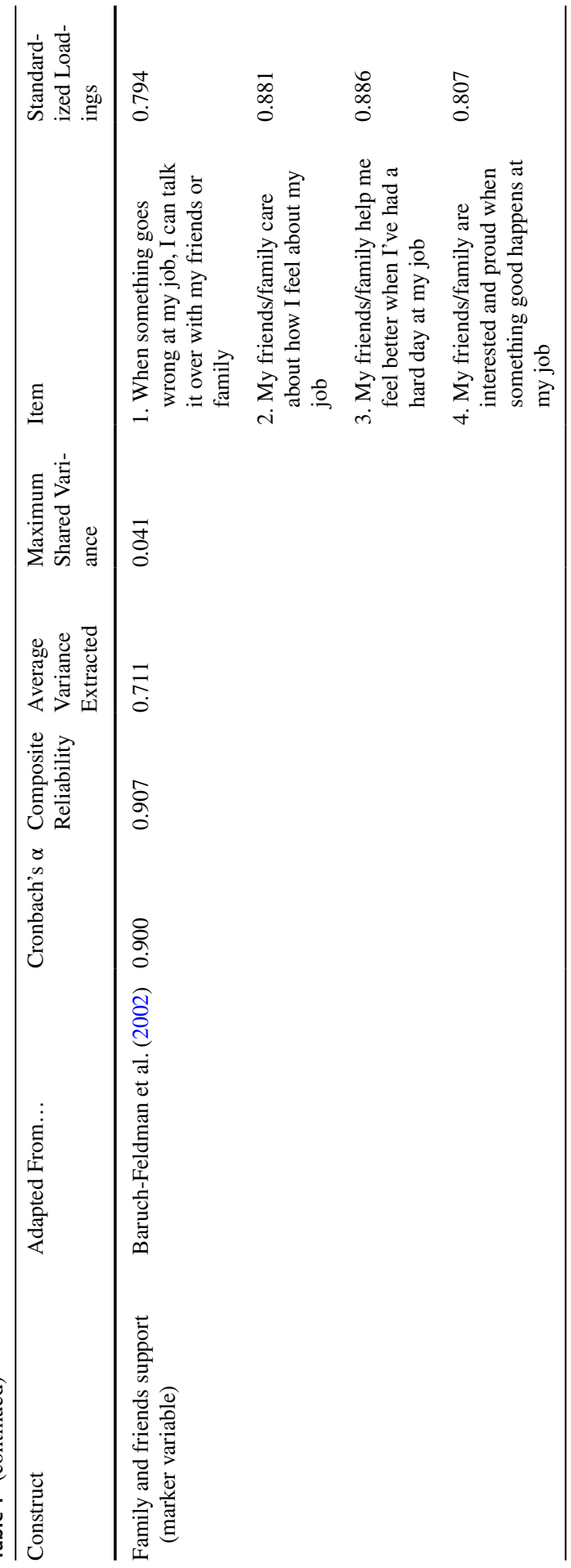




\section{Results}

\subsection{Measurement model}

Table 1 reports the results of the confirmatory factor analysis (CFA; software: AMOS-v.25). All standardized factor loadings appear to be within an acceptable range (0.731-0.986). Cronbach's alpha (range: 0.837-0.956) and composite reliability scores (range: 0.840-0.959) indicate that the measurement model is reliable. All average variance extracted (AVE) scores are higher than 0.5, thus convergent validity is evident in the data (Hair et al. 2010). Discriminant validity is also observed, as all AVE scores exceed the respective maximum shared variances (Fornell and Larcker 1981). Model fit indicators (CFI $=0.939$, TLI $=0.925$, RMSEA $=0.079)$ suggest sufficient model fit.

To detect potential common method biases (CMB), I used the comprehensive CFA marker technique outlined by Williams et al. (2010). I took the four-item construct of "family and friends support" (i.e., support for the person's choice to pursue work as a professional DJ, not support for his or her agency membership) as the marker variable. This was effective because it was theoretically disconnected from the other latent variables, but it nonetheless captured the general theme of the questionnaire (Demirtaş et al. 2019), making it useful for detecting CMBs.

The data show that neither a constrained effect model (model-C) nor an unconstrained effect model (model-U) for the marker variable indicate a significant chi-square change compared to the baseline model (see Appendix A2a). Hence, CMBs do not seem to affect the measurement model. To analyze this in more depth, I calculated the decomposed reliability scores. In model-C, an average of $0.07 \%$ of the total reliability originated from the marker variable. In model-U, an average of $1.71 \%$ of the total reliability originated from the marker variable (see Appendix A2b). Thus, I conclude that CMBs are a minor issue. However, I retained the marker variable in the structural model to be certain that CMBs do not affect structural paths.

Finally, in accordance with the Felps et al. (2009) approach, 18 months after the survey I checked which of the 101 DJs had actually changed their booking agencies. One agency (which represented two DJs) had closed entirely. Of the other 99 DJs, 38 had changed their agency. I compared this actual turnover with the imputed factor score of the turnover intention variable. The resultant correlation coefficient is relatively high $(\mathrm{r}=0.63)$, which indicates the measurement of the turnover intention variable is reliable.

\subsection{Descriptive statistics}

Table 2 shows the descriptive statistics and correlations. The mean level of turnover intention is relatively low (2.217 on a seven-point Likert scale). However, a relatively high standard deviation (1.964) indicates that some DJs rated highly 


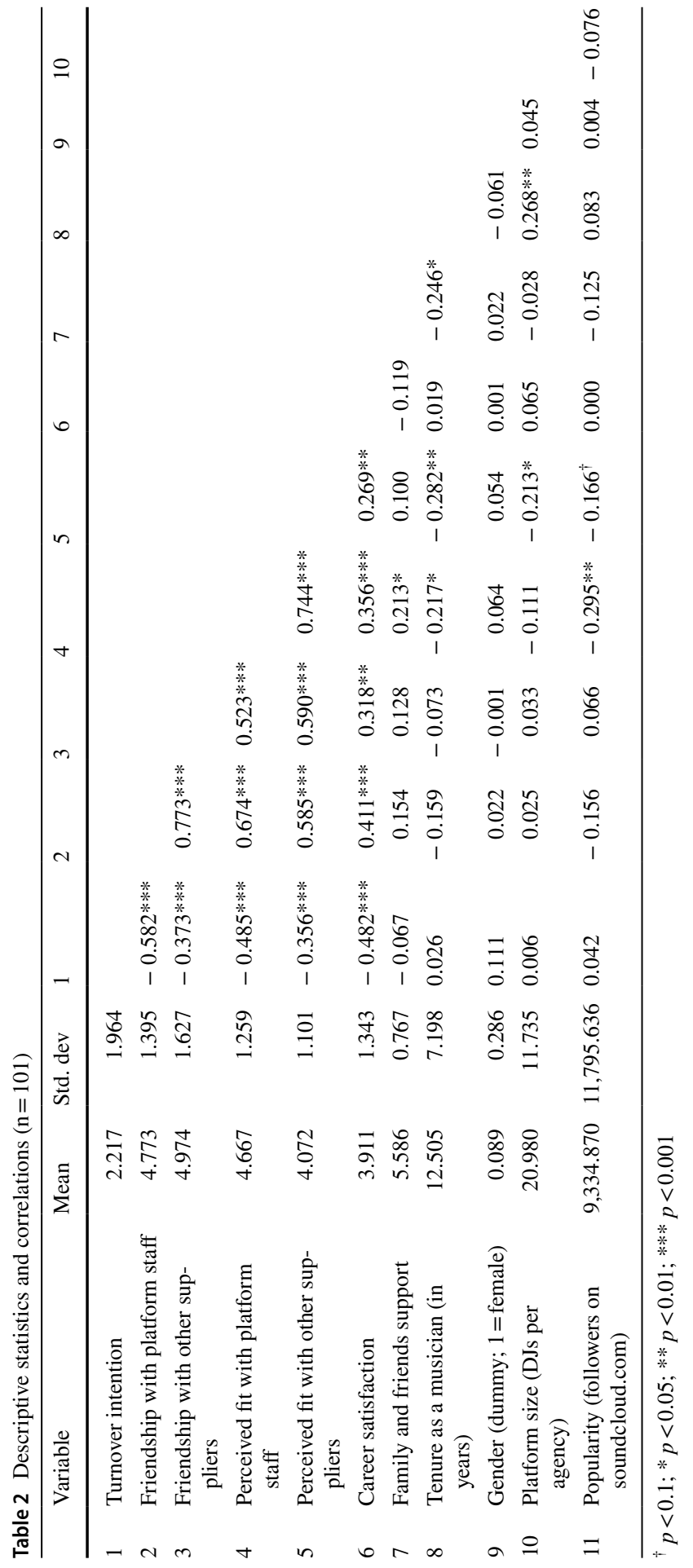


on this variable. The mean values for the friendship variables are relatively high (4.773 for platform staff, 4.974 for other suppliers), demonstrating that DJs regularly maintain friendships at their agencies.

Almost all skewness and kurtosis scores were low, which accorded with my expectations. The exception was the popularity variable, so I transferred this (using the natural logarithm) to the structural model. Variance inflation factors for all variables were adequately low (maximum of 3.527), indicating no multicollinearity issues.

\subsection{Structural model and hypotheses testing}

To test my hypotheses, I used structural equation modeling based on maximum likelihood estimation (software: AMOS-v.25). The results are displayed in Table 3.

Friendship with platform staff negatively affects supplier turnover intention ( $\mathrm{B}=-0.569, \beta=-0.423, p=0.015)$, a result which supports H1a. On a seven-point Likert scale, a one-unit increase in the friendship with platform staff variable leads to a decrease of 0.569 to the turnover intention variable. The standardized effect demonstrates that friendship with platform staff is the strongest predictor of a supplier's turnover intention.

In contrast, friendship with other suppliers does not decrease a supplier's turnover intention. In fact, the insignificant effect is actually positive $(B=0.185, \beta=0.154$, $p=0.314)$. Consequently, $\mathrm{H} 1 \mathrm{~b}$ is rejected.

Looking at the control effects, the two perceived fit variables tell the same story: whereas friendship with other suppliers has no influence on turnover intention ( $\mathrm{B}=-0.020, \beta=-0.011, p=0.941)$, friendship with platform staff has a moderately high negative coefficient $(\mathrm{B}=-0.376, \beta=-0.236, p=0.119)$. The $\mathrm{p}$-value of the perceived fit with the platform staff variable may not be sufficiently low to support a hypothesis in a traditional sense. However, this might be due to the relatively small sample size.

Regarding the other control effects, only career satisfaction has a high significance. More precisely, career satisfaction has a strong negative impact on turnover intention $(\mathrm{B}=-0.378, \beta=-0.263, p=0.009)$. The standardized effect indicates that this is the second-most-important influence on turnover intention.

Model fit indicators suggest sufficient model fit. Furthermore, to check the robustness of my results, I removed all control variables and added a set of different control variables (see Appendix A3). These control variables were not optimal but nonetheless justifiable. They included (a) the DJs' age, (b) whether the agency also functioned as the DJs' record label, (c) whether the agency also managed the DJs' social media activities, (d) previous relationships with platform staff, and (e) previous relationships with other suppliers. However, this process yielded in the same findings for the hypothesis-tests.

Additionally, I calculated a model in which I regressed the actual turnover measured 18 months after the survey (dummy variable) on the two friendship variables. Despite the small sample size $(n=99)$ for a binary logistic regression, this model reproduced the findings of the main model. Friendship with platform staff thus has 


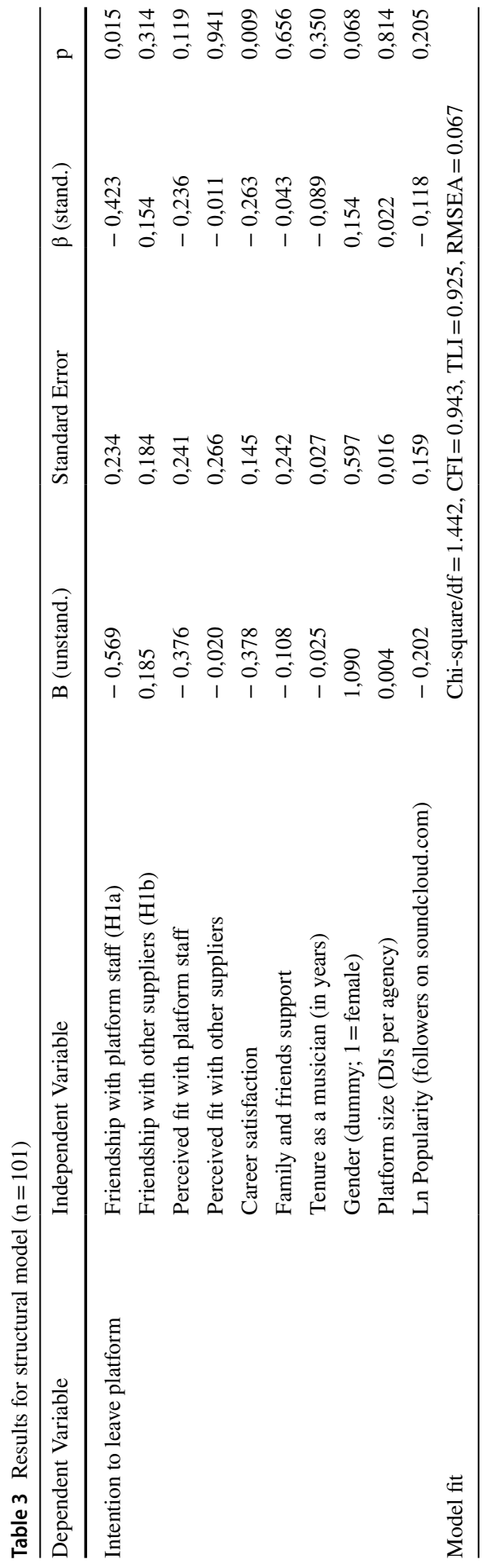


a significant negative effect on actual turnover $(\mathrm{B}=-0.454, p=0.074)$. Friendship with other suppliers has no significant effect on actual turnover $(B=-0.213$, $p=0.337)$.

\section{Discussion}

In this study, I analyzed service suppliers and their intention to leave their platform. I concentrated on the role of interpersonal relationships, which I operationalized as friendships. The study found that friendships with the platform's employees strongly decrease suppliers' turnover intention. However, friendships with other suppliers on the platform do not seem to affect supplier's turnover intention.

The finding for the supplier level may be somewhat surprising. After all, friendships between service suppliers represent a type of embeddedness, and this has been shown to increase loyalty to an organization (Lee et al. 2014). However, there are several reasons why friendships at the supplier level may not decrease turnover intention. For example, service suppliers must interact with the platform's employees to successfully exploit their platform membership (Loux et al. 2020). If such business interactions are complemented by friendship, this often eases resource- and information-sharing (Brawley and Pury 2016). However, many platforms do not require that suppliers have business interactions with one another. Hence, friendships with other suppliers cannot complement platform-related business interactions. In other words, friendships with other suppliers do not create synergies with the platform membership. This indicates that the degree of business interactions might be a moderator of the relationship between friendships and turnover intention (regardless of whether it is a platform organization or a traditional one).

Service suppliers who leave their platform but want to maintain their friendships there may also meet different challenges, depending on the type of friendship. In short, it is much more difficult to maintain friendships with employees at the old platform than it is maintain friendships with other suppliers there. The employees are usually more involved in the activities of the platform, which increases their identification with it (Lin 2019; Riketta 2005). Consequently, the employees may perceive the turnover more negatively than the other suppliers do, which could be more detrimental to the friendship.

Furthermore, friendships between service suppliers are a forum in which to share bad experiences and complaints (D'Cruz and Noronha 2011). Hence, they have the potential to multiply doubts about membership of the platform. In the worst case scenario, the turnover of a single supplier leads to turnover contagion, with the friends of that supplier also deciding to leave (Felps et al. 2009).

Platform companies could use my results to adapt the management practices they use for their service suppliers. This is especially important when the acquisition of valuable suppliers is costly and the platform has only a small number (e.g., bestselling authors and their book publishers). In such cases, the turnover of only a few suppliers can destroy an entire platform (Hom et al. 2017). To prevent this, platforms could implement organizational structures that foster the formation of friendships between service suppliers and platform employees. For example, it 
might be beneficial for platforms to assign a permanent personal contact person to each supplier to increase the likelihood of a friendship formation. Platforms should not assign contact people at random; rather, they should pay close attention to interpersonal fit, as friendships are often formed on the basis of common values and attitudes (Gao et al. 2016). Moreover, platforms should consider how to organize communication with their suppliers. The use of automated data transfers and online communication is an efficient method of interaction, but platforms should also make use of personal communication (e.g., telephone and face-toface conversation).

Moreover, the study findings indicate that employees' friendships with service suppliers are valuable resources - not only for the platform as a whole but also for the employees themselves. For example, Columbia Artists Management Inc., one of the leading agencies in the classical music world for decades, closed in August 2020 (Associated Press 2020). It is likely that Columbia's former employees will use their relationships with suppliers either as assets to obtain positions at other agencies or as key resources at a newly founded agency. However, in other cases, it could pose a risk to the platform if its employees became aware of their valuable assets (i.e., their friendships with suppliers). If employees moved to other platforms, they could take their befriended suppliers with them. As such, it is important to also keep employees loyal if they are to maintain friendships with the suppliers.

Finally, I must highlight two important limitations of my study. First, I focused on turnover intention as an outcome variable, which is not affected by supplier level. However, friendships within the supplier community may still have value for a platform. For instance, they may facilitate mentoring relationships between suppliers (Gardiner 1998) or improve work engagement (Ehrhardt and Ragins 2019). In the long run, this could improve suppliers' performance, which would also benefit the platform. Second, I did not investigate the negative effects of friendships. Workplace friendships can generate conflict, as they occasionally interfere with employees' economic motivations (Grayson 2007; Ingram and Zou 2008). It would thus be valuable to explore the disadvantages of friendships in this context.

\section{Appendix}

See Tables 4, 5, 6, 7. 
Table 4 Most popular German clubs and festivals, 2017

\begin{tabular}{llll}
\hline Club & City & Festival & City/Town \\
\hline ://about blank & Berlin & Airbeat One & Neustadt-Glewe \\
Berghain & Berlin & Docklands Festival & Münster \\
Club der Visionaere & Berlin & Echelon Open Air & Bad Aibling \\
Distillery & Leipzig & Electrisize Festival & Erkelenz \\
Gewölbe & Cologne & Mayday & Dortmund \\
Golden Gate & Berlin & Melt! Festival & Gräfenhainichen \\
Harry Klein & Munich & Nature One & Kastellaun \\
Institut für Zukunft & Leipzig & Open Beatz & Herzogenaurach \\
MMA Club & Munich & Panama Open Air & Bonn \\
Ritter Butzke & Berlin & Ruhr in Love & Oberhausen \\
Robert Johnson & Offenbach & Sea You Festival & Freiburg im Breisgau \\
Rote Sonne & Munich & SonneMondSterne & Saalburg-Ebersdorf \\
Salon Zur Wilden Renate & Berlin & Syndicate & Dortmund \\
Sisyphos & Berlin & Tanzberg & Bonn \\
Suicide Circus & Berlin & Time Warp Festival & Mannheim \\
Tanzhaus West \& Dora Bril- & Frankfurt am Main & Toxicator & Mannheim \\
liant & & & \\
Tresor & Berlin & Utopia Island & Moosburg an der Isar \\
Uebel \& Gefährlich & Hamburg & WinterWorld & Rheinstetten \\
Watergate & Berlin & World Club Dome & Frankfurt am Main \\
Weekend & Berlin & World Club Dome (Winter) & Gelsenkirchen \\
\hline
\end{tabular}




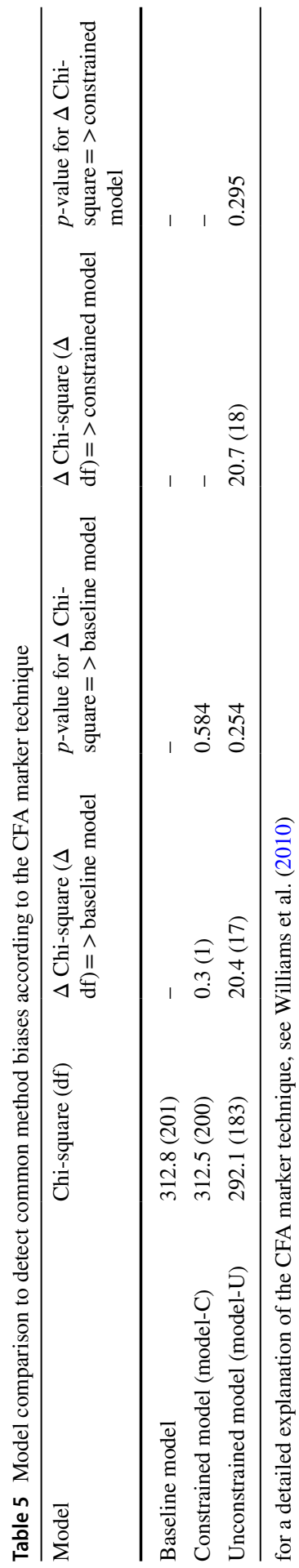




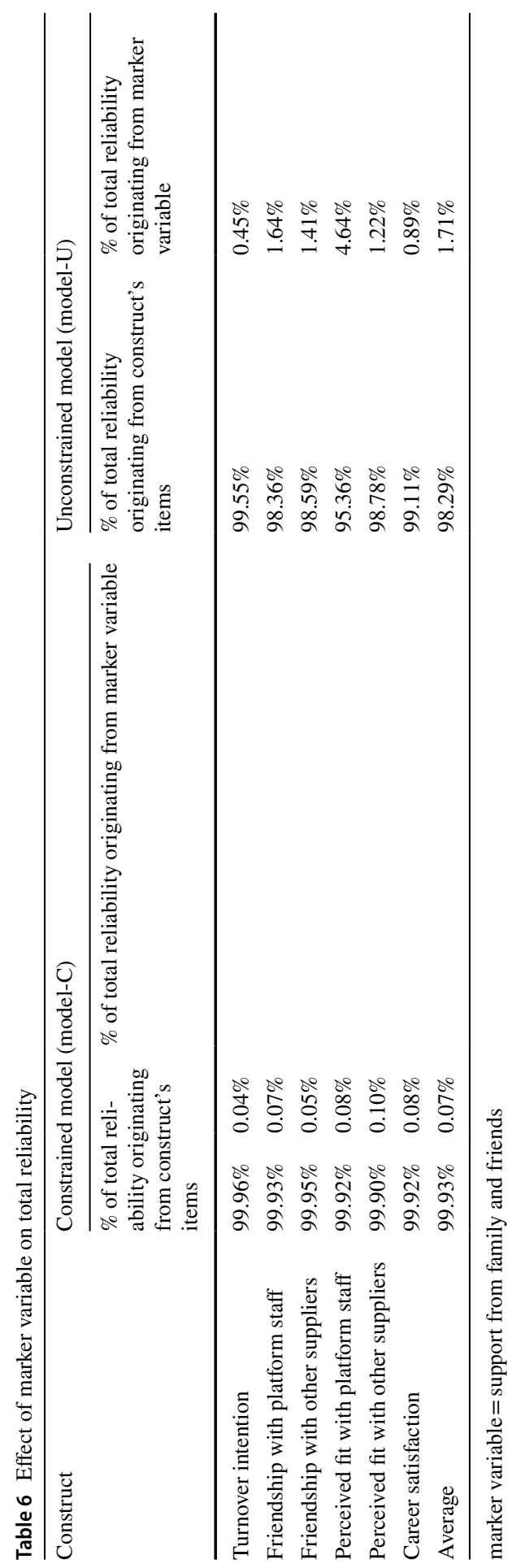




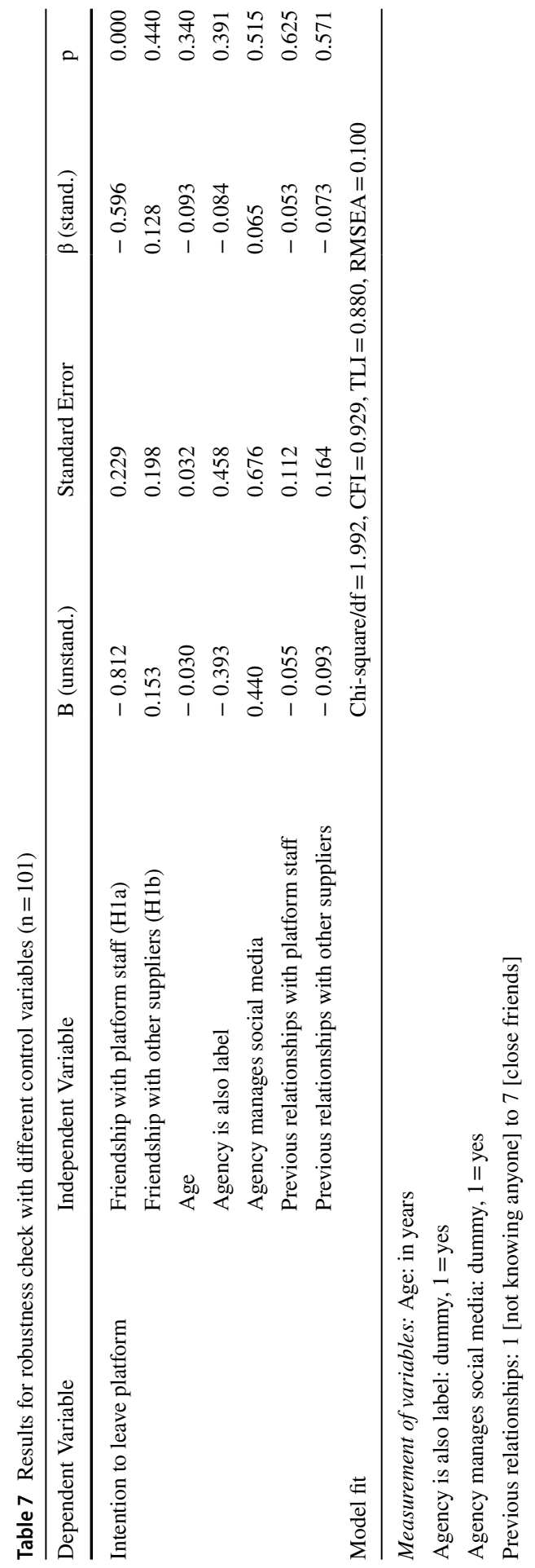


Acknowledgements I would like to thank the following persons for their feedback and support: Sabrina Deck, Alina Smetanin, Sebastian Schönberger, Marius Neun, Simon Balk, Konstantin Reifsteck, Julia Brennecke, Olaf Rank, and Natalie David.

Funding Open Access funding enabled and organized by Projekt DEAL.

\section{Declarations}

Conflicts of interests The author has no relevant financial or non-financial interests to disclose.

Open Access This article is licensed under a Creative Commons Attribution 4.0 International License, which permits use, sharing, adaptation, distribution and reproduction in any medium or format, as long as you give appropriate credit to the original author(s) and the source, provide a link to the Creative Commons licence, and indicate if changes were made. The images or other third party material in this article are included in the article's Creative Commons licence, unless indicated otherwise in a credit line to the material. If material is not included in the article's Creative Commons licence and your intended use is not permitted by statutory regulation or exceeds the permitted use, you will need to obtain permission directly from the copyright holder. To view a copy of this licence, visit http://creativecommons.org/licen ses/by/4.0/.

\section{References}

Akhmedova A, Marimon F, Mas-Machuca M (2020) Winning strategies for customer loyalty in the sharing economy: A mixed-methods study. J Bus Res 112:33-44. https://doi.org/10.1016/j.jbusres.2020. 02.046

Andreassen TW, Lervik-Olsen L, Snyder H, van Riel ACR, Sweeney JC, van Vaerenbergh Y (2018) Business model innovation and value-creation: The triadic way. J Serv Manag 29:883-906. https:// doi.org/10.1108/josm-05-2018-0125

Associated Press (2020) Classical agency Columbia Artists says it will shut down. Associated Press News 2020

Baruch-Feldman C, Brondolo E, Ben-Dayan D, Schwartz J (2002) Sources of social support and burnout, job satisfaction, and productivity. J Occup Health Psychol 7:84-93. https://doi.org/10.1037/10768998.7.1.84

Blomme RJ, van Rheede A, Tromp DM (2010) The use of the psychological contract to explain turnover intentions in the hospitality industry: a research study on the impact of gender on the turnover intentions of highly educated employees. Int J Hum Resour Manag 21:144-162

Boyd NG, Taylor RR (1998) A developmental approach to the examination of friendship in leader-follower relationships. Leadersh Q 9:1-25. https://doi.org/10.1016/S1048-9843(98)90040-6

Brawley AM, Pury CL (2016) Work experiences on MTurk: Job satisfaction, turnover, and information sharing. Comput Hum Behav 54:531-546. https://doi.org/10.1016/j.chb.2015.08.031

Bycio P, Hackett RD, Alvares KM (1990) Job performance and turnover: a review and meta-analysis. Appl Psychol 39:47-76. https://doi.org/10.1111/j.1464-0597.1990.tb01037.x

Cable DM, DeRue DS (2002) The convergent and discriminant validity of subjective fit perceptions. J Appl Psychol 87:875-884. https://doi.org/10.1037/0021-9010.87.5.875

Chen J, Zhang C, Xu Y (2009) The Role of Mutual Trust in Building Members' Loyalty to a C2C Platform Provider. Int J Electron Commer 14:147-171. https://doi.org/10.2753/JEC1086-4415140105

Chen P-C, Wang M-C, Fang S-C (2017) Does motivation matter? the influence of the agency perspective on temporary agency workers. Empl Relat 39:561-581. https://doi.org/10.1108/ER-06-2016-0124

Clauss T, Harengel P, Hock M (2019) The perception of value of platform-based business models in the sharing economy: determining the drivers of user loyalty. Rev Manag Sci 13:605-634. https://doi. org/10.1007/s11846-018-0313-0

Colarelli SM (1984) Methods of communication and mediating processes in realistic job previews. J Appl Psychol 69:633. https://doi.org/10.1037/0021-9010.69.4.633 
Cole D (2013) The DJ Booking Industry: An insider's perspective. https:/www.djbroadcast.net/article/ 98925/the-dj-booking-industry-an-insiders-perspective

Cropanzano R, Anthony EL, Daniels SR, Hall AV (2017) Social exchange theory: a critical review with theoretical remedies. Acad Manag Ann 11:479-516. https://doi.org/10.5465/annals.2015.0099

Damm S, Drevenstedt L (2019) Club Culture Berlin. https://www.clubcommission.de/wp-content/uploa ds/sites/2/2019/10/club-culture-study.pdf

D’Cruz P, Noronha E (2011) The limits to workplace friendship. Empl Relat 33:269-288. https://doi.org/ $10.1108 / 01425451111121777$

Demirtaş Ö, Arslan A, Karaca M (2019) Why perceived organizational and supervisory family support is important for organizations? Evidence from the field. Rev Manag Sci 13:841-869. https://doi.org/ 10.1007/s11846-017-0264-X

Edelman B (2014) Mastering the intermediaries. Harv Bus Rev 92(86-92):138

Ehrhardt K, Ragins BR (2019) Relational attachment at work: a complementary fit perspective on the role of relationships in organizational life. Acad Manag J 62:248-282. https://doi.org/10.5465/amj.2016. 0245

Eisenmann T, Parker G, van Alstyne MW (2006) Strategies for two-sided markets. Harv Bus Rev 84:92

Feeley TH, Hwang J, Barnett GA (2008) Predicting employee turnover from friendship networks. J Appl Commun Res 36:56-73. https://doi.org/10.1080/00909880701799790

Feldman DC, Ng TWH (2007) Careers: mobility, embeddedness, and success. J Manag 33:350-377. https://doi.org/10.1177/0149206307300815

Felps W, Mitchell TR, Hekman DR, Lee TW, Holtom BC, Harman WS (2009) Turnover contagion: how coworkers' job embeddedness and job search behaviors influence quitting. Acad Manag J 52:545561. https://doi.org/10.5465/amj.2009.41331075

Fornell C, Larcker DF (1981) Evaluating structural equation models with unobservable variables and measurement error. J Mark Res 18:39-50. https://doi.org/10.2307/3151312

Frone MR (2015) Relations of negative and positive work experiences to employee alcohol use: testing the intervening role of negative and positive work rumination. J Occup Health Psychol 20:148-160. https://doi.org/10.1037/a0038375

Fu W, Wang Q, Zhao X (2017) The influence of platform service innovation on value co-creation activities and the network effect. J Serv Manag 28:348-388. https://doi.org/10.1108/josm-10-2015-0347

Gao W, Liu Y, Qian L (2016) The personal touch of business relationship: a study of the determinants and impact of business friendship. Asia Pac J Manag 33:469-498. https://doi.org/10.1007/ s10490-016-9464-1

Gardiner C (1998) Mentoring: towards a professional friendship. Mentoring \& Tutoring: Partnership in Learning 6:77-84. https://doi.org/10.1080/0968465980060107

Grayson K (2007) Friendship versus business in marketing relationships. J Mark 71:121-139. https://doi. org/10.1509/jmkg.71.4.121

Hair JF, Black WC, Babin BJ, Anderson RE, Tatham RL (2010) Multivariate data analysis (7th ed.). Prentice hall Upper Saddle River, NJ

Hazée S, Zwienenberg T, van Vaerenbergh Y, Faseur T, Vandenberghe A, Keutgens O (2020) Why customers and peer service providers do not participate in collaborative consumption. J Serv Manag 31:397-419. https://doi.org/10.1108/JOSM-11-2018-0357

Hobfoll SE (1989) Conservation of resources: a new attempt at conceptualizing stress. Am Psychol 44:513. https://doi.org/10.1037/0003-066x.44.3.513

Holtom BC, Mitchell TR, Lee TW, Eberly MB (2008) 5 turnover and retention research: a glance at the past, a closer review of the present, and a venture into the future. Acad Manag Ann 2:231-274. https://doi.org/10.5465/19416520802211552

Hom PW, Lee TW, Shaw JD, Hausknecht JP (2017) One hundred years of employee turnover theory and research. J Appl Psychol 102:530. https://doi.org/10.1037/apl0000103

Huang Q, Chen X, Ou CX, Davison RM, Hua Z (2017) Understanding buyers' loyalty to a C2C platform: the roles of social capital, satisfaction and perceived effectiveness of e-commerce institutional mechanisms. Inf Syst J 27:91-119. https://doi.org/10.1111/isj.12079

Huarng K-H, Yu M-F (2019) Customer satisfaction and repurchase intention theory for the online sharing economy. RMS 13:635-647. https://doi.org/10.1007/s11846-018-0321-0

Ingram P, Zou X (2008) Business friendships. Research in Organizational Behavior 28:167-184. https:// doi.org/10.1016/j.riob.2008.04.006

Jonas JM, Boha J, Sörhammar D, Moeslein KM (2018) Stakeholder engagement in intra- and inter-organizational innovation. J Serv Manag 29:399-421. https://doi.org/10.1108/josm-09-2016-0239 
Kathuria A, Karhade PP, Konsynski BR (2020) In the realm of hungry ghosts: multi-level theory for supplier participation on digital platforms. J Manag Inf Syst 37:396-430. https://doi.org/10.1080/07421 222.2020.1759349

Kiazad K, Holtom BC, Hom PW, Newman A (2015) Job embeddedness: a multifoci theoretical extension. J Appl Psychol 100:641-659. https://doi.org/10.1037/a0038919

Koster F, Stokman F, Hodson R, Sanders K (2007) Solidarity through networks. Empl Relat 29:117-137. https://doi.org/10.1108/01425450710719978

Lee TW, Mitchell TR, Sablynski CJ, Burton JP, Holtom BC (2004) The effects of job embeddedness on organizational citizenship, job performance, volitional absences, and voluntary turnover. Acad Manag J 47:711-722. https://doi.org/10.2307/20159613

Lee TW, Burch TC, Mitchell TR (2014) The story of why we stay: a review of job embeddedness. Annu Rev Organ Psychol Organ Behav 1:199-216. https://doi.org/10.1146/annurev-orgps ych-031413-091244

Lee TW, Hom PW, Eberly MB, Li J, Mitchell TR (2017) On the next decade of research in voluntary employee turnover. Acad Manag Perspect 31:201-221. https://doi.org/10.5465/amp.2016.0123

Lin C-P (2019) Modeling corporate citizenship and turnover intention: social identity and expectancy theories. Rev Manag Sci 13:823-840. https://doi.org/10.1007/s11846-017-0275-7

Lin J-SC, Hsieh C-C (2011) Modeling service friendship and customer compliance in high-contact service relationships. J Serv Manag 22:607-631. https://doi.org/10.1108/09564231111174979

Loux P, Aubry M, Tran S, Baudoin E (2020) Multi-sided platforms in B2B contexts: the role of affiliation costs and interdependencies in adoption decisions. Ind Mark Manage 84:212-223. https://doi.org/ 10.1016/j.indmarman.2019.07.001

Ma X, Khansa L, Kim SS (2018) Active community participation and crowdworking turnover: a longitudinal model and empirical test of three mechanisms. J Manag Inf Syst 35:1154-1187. https://doi. org/10.1080/07421222.2018.1523587

Maertz CP, Stevens MJ, Campion MA (2003) A turnover model for the Mexican maquiladoras. J Vocat Behav 63:111-135. https://doi.org/10.1016/s0001-8791(02)00023-4

Mao H-Y (2006) The relationship between organizational level and workplace friendship. Int J Hum Resour Manag 17:1819-1833. https://doi.org/10.1080/09585190600965316

Martins LL, Eddleston KA, Veiga JF (2002) Moderators of the relationship between work-family conflict and career satisfaction. Acad Manag J 45:399-409. https://doi.org/10.2307/3069354

Meijerink J, Keegan A (2019) Conceptualizing human resource management in the gig economy: Toward a platform ecosystem perspective. J Manag Psychol 34:214-232. https://doi.org/10.1108/ JMP-07-2018-0277

Mitchel JO (1981) The effect of intentions, tenure, personal, and organizational variables on managerial turnover. Acad Manag J 24:742-751. https://doi.org/10.5465/256173

Mitchell TR, Holtom BC, Lee TW, Sablynski CJ, Erez M (2001) Why people stay: Using job embeddedness to predict voluntary turnover. Acad Manag J 44:1102-1121. https://doi.org/10.5465/3069391

Parker G, van Alstyne MW (2014) Platform Strategy. SSRN Journal. https://doi.org/10.2139/ssrn.24393 23

Pillemer J, Rothbard NP (2018) Friends without benefits: understanding the dark sides of workplace friendship. Acad Manag Rev 43:635-660. https://doi.org/10.5465/amr.2016.0309

Price LL, Arnould EJ (1999) Commercial friendships: Service provider-client relationships in context. J Mark 63:38-56. https://doi.org/10.2307/1251973

Riketta M (2005) Organizational identification: A meta-analysis. J Vocat Behav 66:358-384. https://doi. org/10.1016/j.jvb.2004.05.005

Riordan CM, Griffeth RW (1995) The opportunity for friendship in the workplace: An underexplored construct. J Bus Psychol 10:141-154. https://doi.org/10.1007/BF02249575

Ruiner C, Wilkesmann M, Apitzsch B (2019) Staffing agencies in work relationships with independent contractors. Empl Relat 42:525-541. https://doi.org/10.1108/ER-03-2019-0159

Sias PM, Cahill DJ (1998) From coworkers to friends: The development of peer friendships in the workplace. Western Journal of Communication (includes Communication Reports) 62:273-299. https:// doi.org/10.1080/10570319809374611

Sias PM, Heath RG, Perry T, Silva D, Fix B (2004) Narratives of workplace friendship deterioration. J Soc Pers Relat 21:321-340. https://doi.org/10.1177/0265407504042835

Song Y, Escobar O, Arzubiaga U, de Massis A (2021) The digital transformation of a traditional market into an entrepreneurial ecosystem. Rev Manag Sci. https://doi.org/10.1007/s11846-020-00438-5 
Sun M, Tse E (2009) The Resource-Based View of Competitive Advantage in Two-Sided Markets. J Management Studies 46:45-64. https://doi.org/10.1111/j.1467-6486.2008.00796.x

Vardaman JM, Taylor SG, Allen DG, Gondo MB, Amis JM (2015) Translating intentions to behavior: the interaction of network structure and behavioral intentions in understanding employee turnover. Organ Sci 26:1177-1191. https://doi.org/10.1287/orsc.2015.0982

Verquer ML, Beehr TA, Wagner SH (2003) A meta-analysis of relations between person-organization fit and work attitudes. J Vocat Behav 63:473-489. https://doi.org/10.1016/S0001-8791(02)00036-2

Wang Y, Asaad Y, Filieri R (2020) What Makes Hosts Trust Airbnb?: Antecedents of Hosts' Trust toward Airbnb and Its Impact on Continuance Intention. J Travel Res 59:686-703. https://doi.org/10.1177/ 0047287519855135

Williams LJ, Hartman N, Cavazotte F (2010) Method variance and marker variables: A review and comprehensive CFA marker technique. Organ Res Methods 13:477-514. https://doi.org/10.1177/10944 28110366036

Wirtz J, So KKF, Mody MA, Liu SQ, Chun HH (2019) Platforms in the peer-to-peer sharing economy. J Serv Manag 30:452-483. https://doi.org/10.1108/JOSM-11-2018-0369

Zhang L, Fan C, Deng Y, Lam CF, Hu E, Wang L (2019) Exploring the interpersonal determinants of job embeddedness and voluntary turnover: A conservation of resources perspective. Hum Resour Manag J 29:413-432. https://doi.org/10.1111/1748-8583.12235

Publisher's Note Springer Nature remains neutral with regard to jurisdictional claims in published maps and institutional affiliations. 